Authors: D Brimer and A Brimer

THE DEVIL IS IN THE DEFINITION - DEFINITIONS AND THEIR LIMITED USE IN LEGAL PROBLEM SOLVING

2011 VOLUME 14 No 7

http://dx.doi.org/10.4314/pelj.v14i7.7 


\section{THE DEVIL IS IN THE DEFINITION - DEFINITIONS AND THEIR LIMITED USE IN LEGAL PROBLEM SOLVING}

\section{Brimer*}

A Brimer**

\section{Introduction}

Few would argue that South African law has been flooded with legislation since the advent of the Constitution of the Republic of South Africa, 1996. Acts have been published on just about every single aspect of law to bring South Africa up to date with world trends. Accordingly, the Companies Act ${ }^{1}$ has changed and with it have changed all of the traditional structures through which companies do business; in an attempt to get the economy back on track a National Credit Act ${ }^{2}$ has been introduced to combat the reckless granting of credit which has been prevalent in South Africa; a Children's $\mathrm{Act}^{3}$ has been enacted to protect the rights of a child - the list is just about endless. Unfortunately, whilst all of the Acts that have been introduced are very necessary in assisting the law to modernise and fit the ever changing needs of society, many of them suffer from a fundamental flaw which this article seeks to address - the devil of definition.

Consider the following: the National Credit Act (hereinafter referred to as the "Act") has a large definitions section - pages 16 to 28 are devoted to definitions. How might a lawyer then apply these definitions practically in assisting a client who has entered a credit agreement and wants to comply with the Act? Section 129 of the Act sets out certain procedures which must be complied with before one can enforce the payment of a debt due under a credit agreement. In terms of subsection 1 of the Act:

If the consumer is in default under a credit agreement, the credit provider may draw the default to the Notice of the consumer in writing and propose that the consumer refer the credit agreement to a debt counsellor.

* David Brimer. BA, LLB (Rhodes). Partner, Schindlers, Melrose Arch. E-Mail: Brimer@Schindlers.co.za.

** Alan Brimer. BA(UCT), DLitt (UPE). Prof Emeritus, UKZN. E-Mail: Brimer@sainet.co.za.

1 Companies Act 61 of 1973 replaced by the Companies Act 71 of 2008.

2 National Credit Act 34 of 2005.

3 Children's Act 38 of 2005. 
In the practical world, to comply with this requirement an attorney might draft a letter advising the consumer that he/she has the right to refer the matter to a debt counsellor in terms of section 129 of the Act and should he/she fail to do so, legal action will be taken against him/her. This was the course of action taken by a colleague when the Act was newly enacted, when we as attorneys had had little experience in implementing its peremptory provisions. The debt was a relatively minor one and the debtor failed to refer the matter to a debt counsellor as advised in the letter. Thus the matter came before a magistrate who was asked to give judgment for the amount owed under the credit agreement and confirm that section 129 had been complied with as a condition precedent to enforcing the debt. The decision, which was absolutely frustrating given the time taken to get to court, was that "Notice" had not been given, as the letter which notified the debtor of his rights should have called itself a Notice, and the word "Notice" should have appeared clearly on the letter purporting to comply with section 129.

Let us pause now and consider the events as they transpired. An attorney considered the law (including the definitions) and for the first time attempted to invoke the Act to enforce a debt. At what stage does the attorney understand what to do or, put differently, when does the meaning of the law in question become apparent? From the above example it is clear that it is not from the reading of the various definitions that the course of action becomes apparent, but only after the Act has been brought before a court of law. It is then relied upon and interpreted, a precedent is derived, and meaning then devolves for use in future cases.

This may seem fairly simple but it is a point which needs to be driven home to our legislature. Definitions are not of very much use in our law. Rather it is the use of the law itself in a tribunal (a court/arbitration etc) that provides the eventual understanding of how the law works.

What would the Ten Commandments have looked like if they had been drafted by a lawyer? Moses would indubitably have been unable to carry down the slopes of Mount Sinai the stone slabs on which they were engraved. An attempt at drafting just a small part of such a document may be found in the appendix below. 


\section{A philosophical background}

Having in the introductory section of this note described the problem as it is encountered in the practical world, it may be of use to demonstrate on a theoretical level why heavy reliance on definitions is a mistake.

The notion that words do not refer directly to a pre-existing world echoes through the ages. All of us know the metaphor of Plato's cave, ${ }^{4}$ which needs no explication here. Platonism was followed by neo-Platonism, which saw the replacement of the amazing, verbless and therefore timeless first words of the Old Testament - "In the beginning, God" - with the first words of St John's Gospel - "In the beginning was the Word, and the Word was with God, and the Word was God," a formulation which takes cognisance of the time-bound duality of our practical experience of existence, which can be resolved only miraculously - "And the Word was made flesh and dwelt among us... "5 For the ordinary among us the word and reality (which would "flesh" it out) are only mysteriously and vaguely related.

Today's primitive positivists tend to assume that we have direct, unproblematic access to the real world, and go about defining things as if their definitions made immediate sense. Others of our day are more aware. Albert Einstein, for instance, searched in vain for reality in the world of science and found only one constant to rely upon - the speed of light. The rest, he said, was relative. ${ }^{6}$ The literary theorist Derrida (1930-2004) cultivated the habit of deleting his words as he wrote in case

4 The Allegory of the Cave - also known as the Analogy of the Cave, Plato's Cave, or the Parable of the Cave - is an allegory used by the Greek philosopher Plato in his work The Republic. It takes the form of a fictional dialogue between Plato's teacher Socrates and Plato's brother Glaucon, which may be found at the beginning of Book VII (chapter IX in Robin Waterfield's translation) (514a-520a). This is the last such footnote that will be supplied in this contribution, the context of which is a large body of jurisprudence, standard philosophy and general reading and general knowledge. It is difficult to reference lateral thinking, and polite apologies are extended to those who may think that the contribution has not been referenced adequately. Perhaps, though, such readers are among those lawyers who would also want every legal term to be fully and precisely defined? If the reader is dissatisfied and wants further explanation he/she could pick up Plato, Wittgenstein and Dworkin, whose rich ideas can best be understood through their own words.

5 John 1:1 King James Version The Holy Bible.

6 Special relativity was introduced in Einstein's 1905 paper "On the Electrodynamics of Moving Bodies" (Einstein 1905 Annalen der Physik). 
anyone should make the mistake of thinking his words contained essences. Neither of these great thinkers could abide positivism.

The Oxford English Dictionary (the full text, not the Concise or Shorter versions) is wary of definitions. It uses them - true - but perfunctorily, preferring to devote the substance of its text to actual instances of the usage of words in context. For instance, it supplies only 66 senses (by our count) for the word "English," and makes a curt, single-sentence statement about each of these senses. More vitally it supplies 511 instances (again, by our count) of the use of the word in context. One of these in which any attempt at a define of the meaning of the word in this context would require the writing of a book is

2006 D. Winner Those Feet 174 If you support a team that is not rubbish, but plays well and wins, you feel that you are somehow missing out on the spirit of English football. ${ }^{7}$

Note that the context supplied includes where possible a date and a verifiable source, including the identity of the person who used the word in that manner. The similarity to instances of the making of case law is striking, judgments being set in a particular time and place, in a particular context of events and opinions, and attached to a particular personality, that of the lawyer who decides the case.

The date of each entry is essential because words change through time. That statement is trite, but the extent of the change is not self-evident to the man in the street. For instance the Latin mitto, mittere, misi, missum - to send, to abandon, has slipped into a number of different forms, some of them not at first sight clearly related to the original sense of the root: missive, mission, missionary, missile, amiss, dismiss, compromise, message, messenger, mess (a dish on which something is given, as in the biblical "mess of pottage"), and an officers' mess (a room in which the officers are given food), omit, admit, transmit, remit, intermit, commit. It is a long list, and probably incomplete as well. Two of the ordinary words (Germanic rather than Latinate) for a woman in medieval English were burd/byrd, and wyf. Both of them have slipped inexplicably into referring specifically to marriage - bride and wife - but today the word "bird" is also coarse slang for a woman. How did that happen?

7 Let those South Africans who support Manchester United take this entry to heart. 
The term "scholar," rich in reverence, has transformed itself in the Cape into the term "skollie," which has not much reverence about it. Or, still in the Cape, there is the outrageous descent from the divine Hermaphrodite (the child of Hermes and Aphrodite) to the common or garden "moffie." If the meanings of words keep on changing, is there any point in trying to define them? As TS Eliot puts it in Four Quartets, "Words strain,/Crack and sometimes break, under the burden,/Under the tension, slip, slide, perish,/Decay with imprecision, will not stay in place,Will not stay still." ${ }^{8}$ The strain is exerted by time and the weight of reality. It is true that words have meanings. There is no doubt that the world is real - that we do not create it by thinking it into existence. But neither is there any doubt that we can know the world only subjectively, and that there is always a mismatch between what there is to be known, our knowing it, and our attempts to express our knowledge in words. The process of slippage effects every living word (which is one reason why lawyers are fond of the dead language, Latin) and is very obviously still with us today, as is illustrated for instance by the increasing confusion in everyday usage of the words "incidents," "incidence," and "incidences." The process of change is as inexorable as aging. And if that is so, the best conceivable today's definition of a concept, even if written with a scalpel rather than a pen, may be totally accurate today but will be less accurate tomorrow and may be laughable in ten years' time.

The leading philosopher of language in the twentieth century was Wittgenstein. We make this bold statement in good company as professional philosophers in 1999 voted his Philosophical Investigations as the most important work of the twentieth century. ${ }^{9}$ Wittgenstein rejects a variety of ways of thinking about what the meaning of a word is, or how meanings can be identified. He shows how, in each case, our sense of the meaning of the word presupposes our ability to use it. He first asks the reader to perform a thought experiment: to come up with a definition of the word "game." While this may at first seem a simple task, he then goes on to lead us through the problems with different possible definitions of the word "game." Any definition which focuses on amusement leaves us unsatisfied since the feelings experienced by a world-class chess player are very different from those of a group of

8 Eliot Selected Poems 13-18.

9 Lackey 1999 Philosophical Forum 329-346. 
children playing at skipping or Monopoly. Any definition which focuses on competition will fail to explain the game of catch, or the game of solitaire. And a definition of the word "game" which focuses on rules will fall on similar difficulties.

The essential point of this exercise is often missed. Wittgenstein's point is not that it is impossible to define "game," but that we don't have a definition, and that we don't need one, because we use the word successfully even without the definition. ${ }^{10}$ Everybody understands what we mean when we talk about playing a game, and we can even clearly identify and correct inaccurate uses of the word, all without reference to any definition that consists of necessary and sufficient conditions for the use or application of the word game.

He argues that definitions emerge from what he terms "forms of life", which may be seen as the culture and society in which they are used. Wittgenstein stresses the social aspects of cognition: to see how language works we have to see how it functions in a specific social situation. It is this emphasis on becoming attentive to the social backdrop against which language is rendered intelligible that explains Wittgenstein's elliptical comment that "If a lion could talk, we could not understand him". 11

I pause here to make the point that Wittgenstein's views are totally compatible with legal jurisprudence as articulated by Dworkin on how judges reach decisions. He rejects legal positivism, which is the paradigm lurking behind the lawyerly attempt to catch the meaning of a thing by entangling it in a net of words. Dworkin argues that when coming to decisions, Judges rely on principles that are there all along (even before the case has begun) and a judge, when tasked with finding such principles to decide an issue, does this against the current backdrop of the society in which he/she finds him/herself. ${ }^{12}$ Dworkin argues that to discover and apply these principles, courts interpret the legal data (legislation, cases etc.) with a view to articulating an interpretation that best explains and justifies past legal practice. All interpretation must follow from the notion of "law as integrity" to make sense. In the

10 Wittgenstein Philosophical Investigations 66.

11 Wittgenstein Philosophical Investigations 223.

12 Riddall Jurisprudence 99, 311. 
first instance, law must be an internally coherent system. In this way the law, like a web, has an extra layer added to it. ${ }^{13}$

Wittgenstein's forms of life and Dworkin's seamless web should be familiar to any lawyer in the South African legal context. South African judges have frequently used the term public policy to describe that in terms of which judges reach decisions on what the law should be, and this is essentially a reference to the current boni mores of society, which is invoked when weighing competing legal issues and deciding what the law is.

Hear Justice Froneman in Matiso v Commanding Officer, Port Elizabeth Prison putting this principle to use on an actual occasion in an actual case:

The interpretation of the Constitution will be directed at ascertaining the foundational values inherent to the Constitution, whilst the interpretation of the particular legislation will be directed at ascertaining whether that legislation is capable of an interpretation which conforms with the fundamental values or principles of the Constitution. Constitutional interpretation in this sense is thus primarily concerned with the recognition and application of constitutional values and not with a search to find the literal meaning of statutes. The values and principles contained in the Constitution are, and could only be, formulated and expressed in wide and general terms, because they are to be of general application. In terms of the Constitution the courts bear the responsibility of giving specific content to those values and principles in any given situation. In doing so judges will invariably "create" law. ${ }^{14}$

And academics are not ignorant of the principle either:

This paper concerns the meaning of ubuntu. Much of the discussion in academic circles about the concept has involved a search for its proper meaning, or at least a translation that will render the word comprehensible to a wider audience. The most obvious translations were the calques "humanity, personhood or humaneness", but none has been especially helpful. They cannot convey the many connotations in ubuntu nor, of course, its cultural implications.

The search for definition has, unfortunately, proceeded on an assumption that ubuntu refers to some core abstract concept or an actual way of behaving. This paper suggests, however, that a better path to understanding ubuntu is to consider the ways and contexts in which the word is being used. An analysis of this nature assumes that we should pay less attention to predetermined, essentialised

13 Dworkin Law's Empire 104.

14 Matiso v Commanding Officer, Port Elizabeth Prison 19943 BCLR 80 (SE) 87. 
meanings and more to the way in which past and current users are constructing meanings. ${ }^{15}$

\section{Suggestions on how legislation should be drafted}

Our argument is simply that the law should continue to be used and developed by judges as Dworkin has described the process rather than by relying heavily on definitions, a practice which, as Wittgenstein ably demonstrates, is not of much value.

If it is therefore arguable that long definitions sections in legislation are of little use at all, what is the alternative? A piece of South African legislation that has been consistently praised by lawyers of other countries is the Constitution. What then is special about the South African Constitution? Like the Ten Commandments it is a minimalist piece of law, and whilst it guarantees just about every conceivable right or freedom, it gives very little detail of what that right/freedom is. For example, the Constitution provides that every citizen has the right to life, but the word "life" is not defined in the Constitution. The consequence of not providing such a definition is that in the case of $S \vee$ Makwanyane,${ }^{16}$ a landmark judgment in South African jurisprudence, our judges were able to interpret and apply the section protecting the right to life to set aside the death penalty as a contravention of the right. Through use, section 11 of the Constitution has therefore taken on a meaning, and that meaning was derived with reference to the South African social backdrop and the ills and abuses of the death penalty in our past history. In short, the right to life acquired meaning from the society and culture in which the right was to be exercised -as Wittgenstein proposes is the case with all language use.

The dangers of having an over-active legislature obsessed with classification and definition should be all too familiar to South Africans. The Group Areas Act ${ }^{17}$ sought to define certain groups and then keep them in certain defined areas, and the Suppression of Communism $A c t^{18}$ sought to define just about everything as

15 Bennett 2012 PELJ (forthcoming).

16 S v Makwanyane 19953 SA 391 (CC) (S v Makwanyane).

17 Group Areas Act 41 of 1950.

18 Suppression of Communism Act 44 of 1950. 
Communist and thereby suppress it. This approach can result in highly oppressive results, with which we as South Africans are all too familiar.

Our legislature should therefore be enacting legislation lighter in detailed definition and more open to interpretation by a judiciary, so as to ensure that the development of case law as in $S v$ Makwanyane continues into the future and the law remains a living creature, changing with the society it seeks to regulate.

\section{Appendix}

What would the Ten Commandments ${ }^{19}$ have looked like if the Great Legislator had been a lawyer?

That God had lawyerish tendencies is occasionally evident, as in s 10: "Thou shalt not covet thy neighbour's house, thou shalt not covet thy neighbour's wife, his manservant, nor his maidservant, nor his ox, nor his ass, nor anything that is thy neighbour's." 20 But the nature of the list of objects not to be coveted is less than professional. The easy transition from a wife to an ass is not politically correct, and each of these terms requires legal definition in order to qualify as being lawyerly. Of course, the more usual style of the document is relatively terse, as in $s$ : "Honour thy father and thy mother, that thy days may be long upon the land which the Lord thy God giveth thee." Such brevity, if it became common practice in the legal profession, would have a disastrous impact on the accumulation of fees. It is therefore suggested that the document should be appropriately rewritten. The style to be adopted could resemble that of the following definition of the term "father" which is to be found in 5 above:

The term "father", for the purposes of $s 5$, includes

1) A male parent, a sire, a person who answers voluntarily to the name dad, daddy, pa, papa, pappy, pop, pops, "old man";

19 The Decalogue, to be found in Exodus 20:2-17 and Deuteronomy 5:6-21, hereinafter known as the Ten Commandments.

20 All quotations are from the King James version. 
2) A natural/biological father, a birth father, a legal father provided that as the husband of the mother he consented to the artificial insemination of the mother, a surprise father, a posthumous father, a teenage father, a non-parental father, an alleged father provided that such alleged father does not contest the allegation, a sperm donor provided that the husband of the mother did not consent to the mother's artificial insemination;

3) A presumed father, being an individual presumed by the law to be the biological father until shown otherwise ${ }^{21}$ and provided that the presumed father voluntarily allows his name to be placed upon the child's birth certificate.

The term "father", for the purposes of s 5 , does not include

1) An alleged father provided that the alleged father denies the allegation, a step-father, a father-in-law, an adoptive father, a social father, a mother's partner where there is no biological relationship with such a mother's partner, a grandfather, a great grandfather, a great great grandfather, a forefather of generations previous to that of a great great grandfather, a clergyman who is called "father" or "padre" solely by virtue of his being a clergyman, a clergywoman who is called "father" solely by virtue of her being a clergywoman, the Lord thy God (see s 1 above).

21 If a woman conceives or gives birth to a child while married, her husband will be presumed to be the father of the child. It is now generally accepted that approximately 50 percent of such presumptions are wrong. Such a presumption may be tested in a court of law if the child of the presumed father produces evidence to the effect that the DNA of the presumed father does not match his own. 


\section{Bibliography}

Bennett 2012 PELJ

Bennett TW "Ubuntu: an African Equity" 30-61 (forthcoming 2012)

Dworkin Law's Empire

Dworkin R Law's Empire (Harvard University Press Cambridge MA 1986)

Einstein 1905 Annalen der Physik

Einstein A "On the Electrodynamics of Moving Bodies (Zur Elektrodynamik bewegter Körper)" 1905 Annalen der Physik 891-921

Eliot Selected Poems

Eliot TS Selected Poems (Four Quartets) (Faber and Faber London 2009)

Lackey 1999 Philosophical Forum

Lackey D "What Are the Modern Classics? The Baruch Poll of Great Philosophy in the Twentieth Century" 1999 Philosophical Forum 329-346

Plato Republic

Plato The Republic (translated from the Ancient Greek by $\mathrm{R}$ Waterfield) (Oxford University Press Oxford 1993)

Riddall Jurisprudence

Riddall JG Jurisprudence $2^{\text {nd }}$ ed (Butterworths London 1999)

Simpson and Weiner Oxford English Dictionary

Simpson JA and Weiner ESC Oxford English Dictionary $2^{\text {nd }}$ ed (Clarendon Press Oxford 1998)

Wittgenstein Philosophical Investigations

Wittgenstein LJJ Philosophical Investigations (translated from German by GEM Anscombe) (Wiley-Blackwell Hoboken NJ 2001) 


\section{Register of legislation}

Childrens Act 38 of 2005

Companies Act 61 of 1973

Companies Act 71 of 2008

Constitution of the Republic of South Africa, 1996

Group Areas Act 41 of 1950

National Credit Act 34 of 2005

Suppression of Communism Act 44 of 1950

\section{Register of cases}

Matiso v Commanding Officer, Port Elizabeth Prison 19943 BCLR 80 (SE)

$S$ v Makwanyane 19953 SA 391 (CC)

\section{List of abbreviations}

PELJ Potchefstroom Electronic Law Journal 